\title{
PENENTUAN KONSEP PERANCANGAN ALAT PENGERING SIMPLISIA JAHE MENGGUNAKAN SUMBER PANAS SINAR MATAHARI DENGAN BACKUP PANAS KOMPOR BIOMASSA
}

\author{
Ereika Ari Agassi, Retno Wulan Damayanti*), Sukmaji Indro Cahyono \\ Laboratorium Sistem Kualitas, Jurusan Teknik Industri, Universitas Sebelas Maret \\ Jl. Ir. Sutami 36A, Kentingan, Surakarta 57126, Indonesia
}

\begin{abstract}
Abstrak
Proses pengeringan rimpang jahe yang dilakukan petani Biofarmaka Karanganyar untuk memproduksi simplisia, selama ini menggunakan sumber panas sinar matahari. Sinar matahari merupakan sumber energi yang terdapat bebas di alam namun tidak dapat dikontrol. Proses produksi simplisia terhambat apabila tidak terdapat panas matahari yaitu apabila cuaca mendung atau hujan. Hambatan proses produksi simplisia menjadi faktor yang penting mengingat daya tahan jahe segar yang rendah. Untuk itu, diperlukan adanya alternatif sumber energi panas yang murah dan dapat dikontrol untuk memproduksi simplisia jika sumber energi panas matahari tidak dapat digunakan. Penelitian ini bertujuan untuk menyusun konsep perancangan alat pengering simplisia jahe menggunakan sumber panas sinar matahari dengan backup panas kompor biomassa. Tahapan perancangan terdiri dari identifikasi kebutuhan pengguna, penyusunan spesifikasi produk, pengembangan konsep produk, dan pemilihan konsep produk. Penelitian ini menghasilkan 36 konsep produk untuk alat pengering simplisia jahe menggunakan sumber panas sinar matahari.
\end{abstract}

Kata kunci : alat pengering; simplisia; energi matahari; kompor biomassa

\begin{abstract}
The ginger drying process used by Biofarmaka farmers of Karanganyar to produce simplisia, used heat source from solar energy of the sunlight. Sunlight is a free source of energy that can be obtained in the universe but can not be controlled. Production of simplisia can be stopped or obstructed if there is no sunlight that gives solar energy for the drying process (cloudy or rainy). This obstacle of production process of simplisia becomes an important matter considering the low durability of fresh ingredients (ginger). This requires the presence of an additional source of heat energy which is cheap and can be controlled to produce simplisia if the heat source from solar energy of the sunlight can not be used. This study aims to construct concept of design solar dryer with a biomass stove for heat backup to produce ginger simplisia. The step of design are identification of user requirements, construction of product specifications, product concept development, and product concept selection. This study resulted in 36 product concept of the ginger solar dryer.
\end{abstract}

Keywords : dryer; simplisia; solar energy; biomass stove

\section{Pendahuluan}

Simplisia menurut Herawati (2012) merupakan bahan alamiah yang dipergunakan sebagai bahan baku obat tradisional yang belum mengalami pengolahan kecuali proses pengeringan. Simplisia jahe berarti jahe segar yang telah dikeringkan yang siap diolah menjadi obat tradisional. Pengolahan bahan baku alami (jahe segar) menjadi simplisia dilakukan dengan serangkaian proses meliputi proses penyortiran pertama, pencucian,

\footnotetext{
${ }^{*}$ Penulis Korespondensi.

email: rwd@ft.uns.ac.id
}

perajangan (pemotongan), pengeringan, penyortiran kedua, pengemasan (packaging), dan penyimpanan (Sembiring, 2011). Proses pengeringan merupakan proses inti dari proses pembuatan simplisia karena simplisia merupakan bahan alami yang dikeringkan.

Dalam proses pengeringan ini, faktor utama yang berpengaruh adalah suhu. Suhu yang terlalu tinggi dapat menyebabkan kandungan penting pada rimpang jahe (antara lain : ginger role) mudah hilang, sebaliknya jika suhu terlalu rendah mengakibatkan penguapan kadar air berjalan lambat sehingga proses pengeringan lama, dan berpotensi kurang kering yang berdampak pada mudahnya ditumbuhi jamur atau kapang (Fitriani, 2013). Menurut Fitriani (2013), pada umumnya suhu 
pengeringan jahe adalah antara $40-60^{\circ} \mathrm{C}$, dengan suhu paling baik pada $50^{\circ} \mathrm{C}$ untuk mencapai kadar kekeringan sesuai SNI 01-7084-2005 yaitu dengan kadar air pada jahe maksimal 10\%. (Badan Standardisasi Nasional, 2005). Selain itu, untuk mengeringkan simplisia jahe, faktor lain yang perlu diperhatikan adalah tempat pengering jahe harus steril dan tertutup untuk menghindari kotoran dan benda asing tercampur pada simplisia jahe.

Petani biofarmaka di Kabupaten Karanganyar saat melakukan proses pengeringan rimpang jahe segar menjadi simplisia dilakukan dengan metode yang konvensional, yaitu dengan pengeringan terbuka di bawah sinar matahari secara langsung (Open Sun Direct Drying). Masalah yang muncul dari metode pengeringan tersebut adalah sumber energi pengeringan yang bergantung cuaca. Proses produksi simplisia terhambat apabila tidak terdapat panas matahari yaitu saat cuaca mendung atau hujan. Hambatan proses produksi simplisia menjadi faktor yang penting mengingat daya tahan bahan segar yang rendah (maksimal 2 bulan). Proses pengeringan yang lama juga disebabkan oleh pengeringan yang dilakukan hanya pada satu sisi saja karena proses pengeringan memanfaatkan panas sinar matahari secara langsung, sehingga harus dibolak-balik. Selain lama, proses pengeringan dilakukan di tempat yang kurang bersih, yaitu di rak-rak bambu atau di halaman dengan dialasi hamparan terpal di luar rumah para petani.

Susilo, dkk (2014) telah merancang alat pengering simplisia menggunakan energi matahari (solar dryer). Susilo dkk (2014) menghasilkan solar dryer dengan tipe passive indirect solar dryer, yaitu alat pengering dengan memanfaatkan energi matahari, dengan sistem pemanasan tidak langsung dan memanfaatkan aliran udara alami (natural flow). Alat ini mampu mengeringkan rimpang menjadi simplisia secara lebih cepat dan higenis dibandingkan dengan metode pengeringan petani. Namun, hambatan yang masih dimiliki alat ini adalah berkaitan dengan pemanasan yang hanya bersumber pada matahari. Hal ini menjadi kelemahan alat ini saat musim penghujan tiba, karena intensitas matahari rendah untuk menjadi sumber energi panas pengeringan.

Berdasarkan permasalahan tersebut, pada penelitian ini dilakukan penentuan konsep perancangan alat pengering simplisia jahe yang tidak hanya mengandalkan sumber panas sinar matahari, namun ditambahkan backup sumber panas yang berasal dari kompor biomassa. Panas sinar matahari menjadi sumber panas utama pada pengembangan rancangan alat ini, karena ketersediaannya yang melimpah dan bebas di alam. Hal ini didukung lokasi, bahwa Indonesia yang merupakan negara tropis, yang terletak pada daerah katulistiwa sehingga disinari matahari selama 10 hingga 12 jam sehari dengan suhu yang relatif konstan (Widodo, 2009). Rancangan alat pengering ini dilengkapi dengan sistem backup energi panas menggunakan kompor biomassa yang diharapkan dapat menggantikan peran sinar matahari apabila cuaca tidak mendukung (mendung atau hujan) maupun untuk pengeringan di malam hari pada saat tidak terdapat sinar matahari untuk mengatasi hambatan produksi simplisia. Kompor biomassa dipilih menjadi alternatif sumber panas karena biaya operasional yang lebih rendah daripada kompor dengan energi lain (listrik, gas). Petani dapat menggunakan bahan bakar kompor dengan memanfaatkan bahan di sekitar seperti sekam padi dan potongan kayu, atau dapat menggunakan arang.

Alat ini diharapkan dapat mengoptimalkan proses pengeringan jahe untuk pembuatan simplisia. Proses pengeringan simplisia lebih cepat dengan mekanisme pengeringan aliran udara yang memungkinkan pengeringan dilakukan pada kedua sisi sekaligus sehingga tidak perlu dibolak-balik, lebih higenis karena dilakukan pada ruang tertutup (kabinet), serta produksi simplisia dapat dilakukan ketika cuaca mendung atau pada malam hari dengan mekanisme pengeringan bersumber panas kompor biomassa sebagai alternatif sumber panas.

\section{Metodologi Penelitian}

Metode digunakan untuk merancang alat pengering simplisia pada penelitian ini mengacu pada tahapan perancangan produk Ulrich (2001). Perancangan produk menurut Ulrich (2001) merupakan tahapan-tahapan atau urutan langkah perusahaan untuk menyusun, merancang, dan mengkomersialkan suatu produk. Tahapan perancangan yang digunakan pada penelitian ini, yaitu :

1. Identifikasi Kebutuhan Pengguna

Identifikasi kebutuhan pengguna merupakan langkah awal yang menentukan suatu perancangan produk, karena merupakan dasar dan tujuan dari perancangan dan pengembangan suatu produk. Identifikasi kebutuhan pengguna pada penelitian ini dilakukan dengan metode wawancara. Wawancara dilakukan pada petani biofarmaka yang mana merupakan calon pengguna dari alat pengering yang dirancang.

2. Penyusunan Spesifikasi Produk

Spesifikasi produk ditentukan dari hasil identifikasi kebutuhan pengguna. Spesifikasi produk merupakan translasi kebutuhan pengguna menjadi kebutuhan teknis yang harus dicapai produk. Penentuan spesifikasi produk dilakukan oleh tim perancang alat dengan cara diskusi dan brainstorming berdasarkan kebutuhan pengguna yang teridentifikasi.

3. Pengembangan dan Pemilihan Konsep Produk Pada tahap ini, dilakukan penyusunan alternatifalternatif konsep untuk memenuhi masing-masing kebutuhan teknis yang telah ditetapkan. Penyusunan alternatif konsep dilakukan oleh tim perancang alat dengan cara diskusi, brainstorming, dan studi literatur. Kemudian, dari alternatif-alternatif konsep tersebut dilakukan pemilihan alternatif konsep produk yang terbaik dengan cara penilaian. Penilaian dilakukan oleh tim perancang alat dan petani biofarmaka Karanganyar dengan cara diskusi. Besar skor penilaian yaitu 1 hingga 3 poin. Alternatif konsep yang terpilih merupakan alternatif konsep 
yang mendapat skor tertinggi (3 poin).

4. Konsep Produk Terpilih

Konsep produk yang terpilih merupakan kombinasi dari konsep produk yang mendapat skor tertinggi. Dari konsep produk tersebut kemudian dapat disusun gambaran produk secara umum dan sistem kerja alat pengering yang dirancang.

\section{Hasil Dan Pembahasan}

1. Identifikasi Kebutuhan Pengguna

Identifikasi kebutuhan pengguna dilakukan dengan metode wawancara kepada petani biofarmaka Karanganyar sesuai yang telah dijelaskan pada metode penelitian. Dari hasil wawancara diperoleh 8 kebutuhan pengguna untuk perancangan alat pengering simplisia jahe yang ditunjukkan pada tabel 1.

2. Penyusunan Kebutuhan Teknis

Dari 8 kebutuhan pengguna yang teridentifikasi, kemudian dilakukan penyusunan kebutuhan teknis untuk memenuhi kebutuhan pengguna tersebut. Dari hasil identifikasi, diperoleh 18 kebutuhan teknis perancangan alat pengering yang ditunjukkan pada tabel 2.

3. Pengembangan dan Pemilihan Konsep Produk Pengembangan konsep produk dibagi menjadi 3 bagian, yaitu :

a) Konsep untuk pengeringan bersumber panas matahari

Pada tahap ini dilakukan pengembangan konsep produk untuk pengeringan bersumber panas matahari guna memenuhi kebutuhan teknis yang telah ditetapkan. Dari proses pengembangan, didapatkan 8 konsep untuk pengeringan bersumber panas matahari. Masing-masing konsep mempunyai 1 hingga 3 alternatif untuk memenuhi kebutuhan yang ditetapkan. Setelah itu dilakukan penilaian terhadap alternatif-alternatif konsep tersebut untuk menentukan alternatif konsep terpilih yang digunakan sebagai konsep rancangan alat pengering. Hasil pengembangan dan pemilihan konsep produk untuk alat pengering secara keseluruhan ditunjukkan pada tabel 3 .

b) Konsep untuk pengeringan bersumber panas kompor biomassa

Pada tahap ini dilakukan pengembangan konsep produk untuk pengeringan bersumber panas kompor biomassa guna memenuhi kebutuhan teknis yang telah ditetapkan. Dari proses pengembangan, didapatkan 15 konsep untuk pengeringan bersumber panas kompor biomassa. Masing-masing konsep mempunyai 1 hingga 3 alternatif untuk memenuhi kebutuhan yang ditetapkan. Setelah itu, dilakukan penilaian terhadap alternatif-alternatif konsep tersebut untuk menentukan alternatif konsep terpilih yang digunakan sebagai konsep rancangan alat pengering. Hasil pengembangan dan pemilihan konsep produk untuk alat pengering secara keseluruhan ditunjukkan pada tabel 4 .

c) Konsep untuk alat pengering secara keseluruhan Pada tahap ini dilakukan pengembangan konsep produk untuk alat pengering secara keseluruhan guna memenuhi kebutuhan teknis yang telah ditetapkan. Dari proses pengembangan, didapatkan 13 konsep untuk alat pengering secara keseluruhan. Masing-masing konsep mempunyai 1 hingga 3 alternatif untuk memenuhi kebutuhan yang ditetapkan. Setelah itu, dilakukan penilaian terhadap alternatif-alternatif konsep tersebut untuk menentukan alternatif konsep terpilih yang digunakan sebagai konsep rancangan alat pengering. Hasil pengembangan dan pemilihan konsep produk untuk alat pengering secara keseluruhan ditunjukkan pada tabel 5 .

Tabel 1. Kebutuhan Pengguna

\begin{tabular}{|c|l|}
\hline No & \multicolumn{1}{|c|}{ Kebutuhan Pengguna } \\
\hline 1 & Alat pengering mudah digunakan \\
\hline 2 & Alat pengering bersumber kompor murah untuk beroperasi \\
\hline 3 & Perawatan Alat pengering mudah dan murah \\
\hline 4 & Alat pengering mudah disimpan dan dipindah \\
\hline 5 & Alat pengering awet dan kuat \\
\hline 6 & $\begin{array}{l}\text { Alat pengering mampu mengeringkan jahe menjadi simplisia yang dapat } \\
\text { diterima industri atau pasar (lebih baik dari penjemuran langsung di alam } \\
\text { terbuka) }\end{array}$ \\
\hline 7 & Alat pengering mampu menampung banyak rimpang \\
\hline 8 & Alat pengering mampu dibuat secara mandiri oleh petani \\
\hline
\end{tabular}


Tabel 2. Kebutuhan Teknis

\begin{tabular}{|c|c|c|c|}
\hline No & Kebutuhan Pengguna & No & Kebutuhan Teknis \\
\hline \multirow{3}{*}{1} & \multirow{3}{*}{ Alat pengering mudah digunakan } & 1 & Set up alat mudah dilakukan \\
\hline & & 2 & loading/unloading rimpang jahe mudah dilakukan \\
\hline & & 3 & $\begin{array}{c}\text { Pengeringan Simplisia jahe dilakukan pada kedua sisi } \\
\text { sekaligus (Tidak perlu dibolak-balik) }\end{array}$ \\
\hline 2 & $\begin{array}{l}\text { Alat pengering bersumber kompor } \\
\text { murah untuk beroperasi }\end{array}$ & 4 & $\begin{array}{c}\text { Bahan bakar kompor terjangkau harganya atau dapat } \\
\text { diperoleh di lingkungan desa Klaster Biofarmaka } \\
\text { karanganyar }\end{array}$ \\
\hline \multirow{2}{*}{3} & \multirow{2}{*}{$\begin{array}{l}\text { Perawatan Alat pengering mudah } \\
\text { dan murah }\end{array}$} & 5 & $\begin{array}{c}\text { Perakitan komponen dan perbaikannya dapat dilakukan } \\
\text { secara mandiri oleh petani }\end{array}$ \\
\hline & & 6 & Biaya komponen terjangkau petani \\
\hline 4 & $\begin{array}{l}\text { Alat pengering mudah disimpan dan } \\
\text { dipindah }\end{array}$ & 7 & $\begin{array}{l}\text { Pemindahan Alat pengering dapat dilakukan oleh minimal } \\
\qquad 2 \text { orang }\end{array}$ \\
\hline \multirow{3}{*}{5} & \multirow{3}{*}{ Alat pengering awet dan kuat } & 8 & $\begin{array}{l}\text { Alat Pengering Tahan terhadap suhu luar (panas matahari } \\
\text { dan malam hari) }\end{array}$ \\
\hline & & 9 & Alat pengering tahan terhadap air hujan \\
\hline & & 10 & Kompor Alat pengering tahan terhadap panas api \\
\hline \multirow{4}{*}{6} & \multirow{4}{*}{$\begin{array}{c}\text { Alat pengering mampu } \\
\text { mengeringkan jahe menjadi simplisia } \\
\text { yang dapat diterima industri atau } \\
\text { pasar (lebih baik dari penjemuran } \\
\text { langsung di alam terbuka) }\end{array}$} & 11 & Collector mampu menyerap panas dengan baik \\
\hline & & 12 & Panas pada kabinet pengering rata pada seluruh bagian \\
\hline & & 13 & Simplisia jahe yang dihasilkan higenis \\
\hline & & 14 & $\begin{array}{c}\text { Kandungan penting pada jahe tidak hilang (suhu } \\
\text { pengeringan } 40-60^{\circ} \mathrm{C} \text { ) }\end{array}$ \\
\hline 7 & $\begin{array}{c}\text { Alat pengering mampu menampung } \\
\text { banyak rimpang }\end{array}$ & 15 & Area pengeringan simplisia luas \\
\hline 8 & $\begin{array}{l}\text { Alat pengering mampu dibuat } \\
\text { secara mandiri oleh petani }\end{array}$ & 16 & $\begin{array}{c}\text { Assembly atau rancang bangun alat sederhana sesuai } \\
\text { dengan skill/ketrampilan petani serta biaya material yang } \\
\text { terjangkau }\end{array}$ \\
\hline
\end{tabular}

Tabel 3. Konsep untuk Pengeringan Bersumber Panas Matahari

\begin{tabular}{|l|l|l|l|l|l|c|}
\hline \multicolumn{1}{|c|}{ Konsep } & \multicolumn{1}{|c|}{ Alternatif 1 } & Skor & \multicolumn{1}{|c|}{ Alternatif 2 } & Skor & \multicolumn{1}{|c|}{ Alternatif 3 } & Skor \\
\hline $\begin{array}{l}\text { Desain Collector dengan Kabinet } \\
\text { Pengering }\end{array}$ & Permanen & 2 & Semi Permanen & 1 & Dapat dilepas & 3 \\
\hline Material solar collector & Seng & 3 & Plat Stainless & 1 & $\begin{array}{l}\text { Flat plate air- } \\
\text { heating solar } \\
\text { collector }\end{array}$ & 2 \\
\hline Kemiringan collector & $15^{0}$ & 3 & $30^{0}$ & 2 & $45^{0}$ & 1 \\
\hline Ketebalan kaca collector & $3 \mathrm{~mm}$ & 2 & $4 \mathrm{~mm}$ & 1 & $5 \mathrm{~mm}$ & 3 \\
\hline Desain Mekanisme Solar Dryer & $\begin{array}{l}\text { Direct dan Indirect } \\
\text { (mixed) }\end{array}$ & 3 & & - & - & - \\
\hline Letak Direct Dryer & Atas Kabinet & 3 & Samping kabinet & 2 & $\begin{array}{l}\text { Depan/belakang } \\
\text { Kabinet }\end{array}$ & 1 \\
\hline Desain Direct Dryer & Datar & 2 & Miring & 3 & & - \\
\hline Tebal kaca direct dryer & $3 \mathrm{~mm}$ & 2 & $4 \mathrm{~mm}$ & 1 & $5 \mathrm{~mm}$ & 3 \\
\hline
\end{tabular}


Tabel 4. Konsep untuk pengeringan bersumber panas kompor biomassa

\begin{tabular}{|c|c|c|c|c|c|c|}
\hline Konsep & Alternatif 1 & Skor & Alternatif 2 & Skor & Alternatif 3 & Skor \\
\hline $\begin{array}{l}\text { Desain Kompor biomassa dengan } \\
\text { kabinet pengering }\end{array}$ & Permanen & 2 & Semi Permanen & 1 & Dapat Dilepas & 3 \\
\hline Desain Letak Kompor Biomassa & Bawah Kabinet & 3 & Samping Kabinet & 2 & Depan Kabinet & 1 \\
\hline Design Bentuk kompor Biomassa & Tabung & 2 & Kotak & 3 & Mixed & 1 \\
\hline Ukuran Kompor Biomassa & $\begin{array}{l}\text { panjang minimal } \\
30 \mathrm{~cm}\end{array}$ & 2 & $\begin{array}{l}\text { panjang minimal } \\
40 \mathrm{~cm}\end{array}$ & 3 & $\begin{array}{l}\text { panjang minimal } 50 \\
\mathrm{~cm}\end{array}$ & 1 \\
\hline Jenis Bahan Bakar Biomassa & Sekam Padi & 2 & Kayu Bakar & 3 & Arang & 1 \\
\hline Material komponen kompor & Aluminium & 3 & Stainless Steel & 2 & Besi & 1 \\
\hline $\begin{array}{l}\text { Ketebalan material komponen } \\
\text { kompor }\end{array}$ & $0,6 \mathrm{~mm}$ & 1 & $0,8 \mathrm{~mm}$ & 3 & $1 \mathrm{~mm}$ & 2 \\
\hline $\begin{array}{l}\text { Mekanisme perluasan panas } \\
\text { kompor }\end{array}$ & $\begin{array}{l}\text { Adanya heat } \\
\text { exchenger pada } \\
\text { ruang pengering }\end{array}$ & 3 & - & - & - & - \\
\hline Desain heat exchanger & Berongga (jaring) & 3 & Plat & 2 & - & \\
\hline Material heat exchanger & Aluminium & 3 & Stainless Steel & 2 & Seng & 1 \\
\hline $\begin{array}{l}\text { Desain pembuangan asap } \\
\text { pembakaran kompor }\end{array}$ & $\begin{array}{l}\text { Terpisah dengan } \\
\text { aliran udara panas }\end{array}$ & 3 & - & - & - & - \\
\hline Jalur pembuangan asap & $\begin{array}{l}\text { Samping ruang } \\
\text { kabinet }\end{array}$ & 1 & $\begin{array}{l}\text { Belakang/depan } \\
\text { ruang kabinet }\end{array}$ & 2 & $\begin{array}{l}\text { Dalam ruang } \\
\text { kabinet }\end{array}$ & 3 \\
\hline Material Pipa pembuangan asap & Pipa besi & 3 & Pipa Aluminium & 2 & Pipa Stailess steel & 1 \\
\hline $\begin{array}{l}\text { Desain mekanisme kompor } \\
\text { biomass }\end{array}$ & $\begin{array}{l}\text { Adanya pengatur } \\
\text { suhu dalam ruang } \\
\text { kabinet }\end{array}$ & 3 & - & - & - & - \\
\hline $\begin{array}{l}\text { Desain mekanisme pengatur suhu } \\
\text { kompor }\end{array}$ & Termostat & 3 & - & - & - & - \\
\hline
\end{tabular}

Tabel 5. Konsep untuk alat pengering secara keseluruhan

\begin{tabular}{|l|l|l|l|l|l|c|}
\hline \multicolumn{1}{|c|}{ Konsep } & \multicolumn{1}{|c|}{ Alternatif 1 } & Skor & \multicolumn{1}{|c|}{ Alternatif 2 } & Skor & \multicolumn{1}{|c|}{ Alternatif 3 } & Skor \\
\hline $\begin{array}{l}\text { Mekanisme mobilitas alat } \\
\text { jahe }\end{array}$ & Roda & 3 & Bantalan Karet & 2 & - & - \\
\hline $\begin{array}{l}\text { Mekanisme mempermudah } \\
\text { loading/unloading }\end{array}$ & $\begin{array}{l}\text { adanya handle } \\
\text { pada wadah } \\
\text { pengering }\end{array}$ & 3 & Semi Permanen & 1 & Dapat dilepas & 3 \\
\hline $\begin{array}{l}\text { Desain Letak Handle wadah } \\
\text { pengering }\end{array}$ & Depan & 3 & Samping & - & & - \\
\hline Material handle & Kayu & 3 & Aluminium & 2 & Besi \\
\hline $\begin{array}{l}\text { Desain jenis material wadah } \\
\text { pengering }\end{array}$ & Berongga (jaring) & 3 & & - & & - \\
\hline $\begin{array}{l}\text { Material bagian luar Alat (outer } \\
\text { box) }\end{array}$ & Kayu & 3 & Seng & 2 & Besi Galvanis & 1 \\
\hline Desain posisi wadah pengering & Datar & 2 & Miring 6 & 3 & Miring 10 & - \\
\hline Material wadah pengering & Aluminium & 3 & Stainless Steel & 2 & Galvanis & 1 \\
\hline $\begin{array}{l}\text { Desain Lubang inlet (udara masuk) } \\
\text { Depan collector }\end{array}$ & 2 & Samping collector & 1 & Bawah collector & 3 \\
\hline $\begin{array}{l}\text { Desain lubang exhaust (udara } \\
\text { keluar) }\end{array}$ & Atas Kabinet & 3 & $\begin{array}{l}\text { Belakang/depan } \\
\text { Kabinet }\end{array}$ & 2 & Samping Kabinet & 1 \\
\hline $\begin{array}{l}\text { Desain mekanisme wadah } \\
\text { pengering }\end{array}$ & Sistem rak & 3 & & - & & - \\
\hline Jarak antar rak & 5 cm & 2 & 8 cm & 3 & 10 cm & - \\
\hline
\end{tabular}

4. Konsep Produk terpilih

Konsep produk yang terpilih merupakan kombinasi dari konsep produk yang mendapat skor tertinggi. Konsep produk yang terpilih berdasarkan hasil penilaian ditunjukkan pada tabel 6 .

Dari konsep produk tersebut kemudian dapat disusun gambaran produk secara umum dan sistem kerja alat pengering yang dirancang. Rancangan alat pengering pada penelitian ini mempunyai dua sumber energi panas yang digunakan untuk proses pengeringan, yaitu sumber panas dari sinar matahari dan sumber panas dari kompor biomassa yang bersifat sabagai backup panas.

Gambar 1 menunjukkan sistem kerja alat pengering bersumber panas matahari. sistem kerja alat pengering bersumber panas matahari menggunakan 
gabungan dari dua mekanisme pengeringan sesuai dengan konsep yang terpilih, yaitu mekanisme yang memanfaatkan panas matahari secara langsung (direct) dan mekanisme yang memanfaatkan panas matahari secara tidak langsung (indirect). Kerja mekanisme pengeringan secara direct (langsung) yaitu panas matahari masuk pada ruang pengering melalui media kaca pada bagian atas kabinet dan terperangkap pada ruang pengering sehingga memanaskan rimpang yang ada pada ruang pengering. Kadar air rimpang berubah menjadi uap akibat radiasi panas sinar matahari kemudian keluar bersama udara melalui lubang exhaust. Kerja mekanisme pengeringan secara indirect ialah aliran udara luar yang masuk pada ruang pengumpul panas (collector) melalui lubang inlet menjadi udara panas setelah melewati material penyerap panas yang telah menyerap panas matahari (solar collector). Kemudian udara panas tersebut dialirkan pada ruang pengeringan untuk mengeringkan rimpang. Udara panas tersebut menyerap kadar air rimpang menjadi uap yang kemudian dikeluarkan melalui lubang exhaust.

Gambar 2 menunjukkan sistem kerja alat pengering bersumber panas kompor biomassa. Mekanisme pengeringan bersumber panas kompor biomassa memanfaatkan tiga material penyerap panas yaitu pipa pembuangan asap pembakaran kompor yang didesain di dalam kabinet pengering, material aluminium kompor yang ada di bawah kabinet pengering, serta material heat exchanger yang menempel pada pipa pembuangan asap kompor. Aliran udara yang masuk ke dalam ruang pengering menjadi udara panas karena mendapat panas dari ketiga material penyerap panas tersebut yang kemudian dialirkan melewati rak-rak pengeringan rimpang. Udara panas tersebut akan menyerap kadar air rimpang menjadi uap yang kemudian keluar ruang pengeringan melalui lubang exhaust.

Tabel 6. Konsep Produk Terpilih

\begin{tabular}{|c|c|c|c|c|c|}
\hline No & Konsep & Alternatif & No & Konsep & Alternatif \\
\hline 1 & $\begin{array}{l}\text { Desain Collector dengan Kabinet } \\
\text { Pengering }\end{array}$ & Dapat dilepas & 20 & Jalur pembuangan asap & $\begin{array}{l}\text { Dalam ruang } \\
\text { kabinet }\end{array}$ \\
\hline \multirow[b]{2}{*}{2} & \multirow[b]{2}{*}{ Material solar collector } & \multirow[b]{2}{*}{ Seng } & 21 & Material Pipa pembuangan asap & Pipa besi \\
\hline & & & \multirow[t]{2}{*}{22} & \multirow{2}{*}{$\begin{array}{l}\text { Desain mekanisme kompor } \\
\text { biomass }\end{array}$} & \multirow{2}{*}{$\begin{array}{l}\text { Adanya pengatur } \\
\text { suhu dalam ruang } \\
\text { kabinet }\end{array}$} \\
\hline 3 & Kemiringan collector & $60^{\circ}$ & & & \\
\hline 4 & Ketebalan kaca collector & $5 \mathrm{~mm}$ & \multirow{2}{*}{23} & \multirow{2}{*}{$\begin{array}{l}\text { Desain mekanisme pengatur suhu } \\
\text { kompor }\end{array}$} & \multirow{2}{*}{ Termostat } \\
\hline \multirow{2}{*}{5} & \multirow{2}{*}{ Desain Mekanisme Solar Dryer } & \multirow{2}{*}{$\begin{array}{l}\text { Direct dan Indirect } \\
\text { (mixed) }\end{array}$} & & & \\
\hline & & & 24 & Mekanisme mobilitas alat & Roda \\
\hline 6 & Letak Direct Dryer & Atas Kabinet & 25 & $\begin{array}{l}\text { Desain Tempat (wadah) pengering } \\
\text { jahe }\end{array}$ & Dapat dilepas \\
\hline 7 & Desain Direct Dryer & Miring & \multirow{3}{*}{26} & \multirow{3}{*}{$\begin{array}{l}\text { Mekanisme mempermudah } \\
\text { loading/unloading }\end{array}$} & \multirow{3}{*}{$\begin{array}{l}\text { adanya handle } \\
\text { pada wadah } \\
\text { pengering }\end{array}$} \\
\hline 8 & Tebal kaca direct dryer & $5 \mathrm{~mm}$ & & & \\
\hline \multirow{2}{*}{9} & \multirow{2}{*}{$\begin{array}{l}\text { Desain Kompor biomassa dengan } \\
\text { kabinet pengering }\end{array}$} & \multirow{2}{*}{ Dapat Dilepas } & & & \\
\hline & & & \multirow{2}{*}{27} & \multirow{2}{*}{$\begin{array}{l}\text { Desain Letak Handle wadah } \\
\text { pengering }\end{array}$} & \multirow{2}{*}{ Depan } \\
\hline 10 & Desain Letak Kompor Biomassa & Bawah Kabinet & & & \\
\hline 11 & Design Bentuk kompor Biomassa & Kotak & 28 & Material handle & Kayu \\
\hline 12 & Ukuran Kompor Biomassa & $\begin{array}{l}\text { panjang minimal } \\
40 \mathrm{~cm}\end{array}$ & 29 & $\begin{array}{l}\text { Desain jenis material wadah } \\
\text { pengering }\end{array}$ & Berongga (jaring) \\
\hline 13 & Jenis Bahan Bakar Biomassa & Kayu Bakar & \multirow{2}{*}{30} & \multirow{2}{*}{$\begin{array}{l}\text { Material bagian luar Alat (outer } \\
\text { box) }\end{array}$} & \multirow{2}{*}{ Kayu } \\
\hline 14 & Material komponen kompor & Aluminium & & & \\
\hline \multirow{2}{*}{15} & \multirow{2}{*}{$\begin{array}{l}\text { Ketebalan material komponen } \\
\text { kompor }\end{array}$} & \multirow{2}{*}{$0,8 \mathrm{~mm}$} & 31 & Desain posisi wadah pengering & Miring $6^{\circ}$ \\
\hline & & & 32 & Material wadah pengering & Aluminium \\
\hline \multirow[t]{2}{*}{16} & \multirow{2}{*}{$\begin{array}{l}\text { Mekanisme perluasan panas } \\
\text { kompor }\end{array}$} & \multirow{2}{*}{$\begin{array}{l}\text { Adanya heat } \\
\text { exchenger pada } \\
\text { ruang pengering }\end{array}$} & 33 & Desain Lubang inlet (udara masuk) & Bawah collector \\
\hline & & & \multirow{2}{*}{34} & \multirow{2}{*}{$\begin{array}{l}\text { Desain lubang exhaust (udara } \\
\text { keluar) }\end{array}$} & \multirow{2}{*}{ Atas Kabinet } \\
\hline 17 & Desain heat exchanger & Berongga (jaring) & & & \\
\hline 18 & Material heat exchanger & Aluminium & 35 & Desain mekanisme wadah & Sistem rak \\
\hline 19 & Desain pembuangan asap & Terpisah dengan & 35 & pengering & \\
\hline 19 & pembakaran kompor & aliran udara panas & 36 & Jarak antar rak & $8 \mathrm{~cm}$ \\
\hline
\end{tabular}




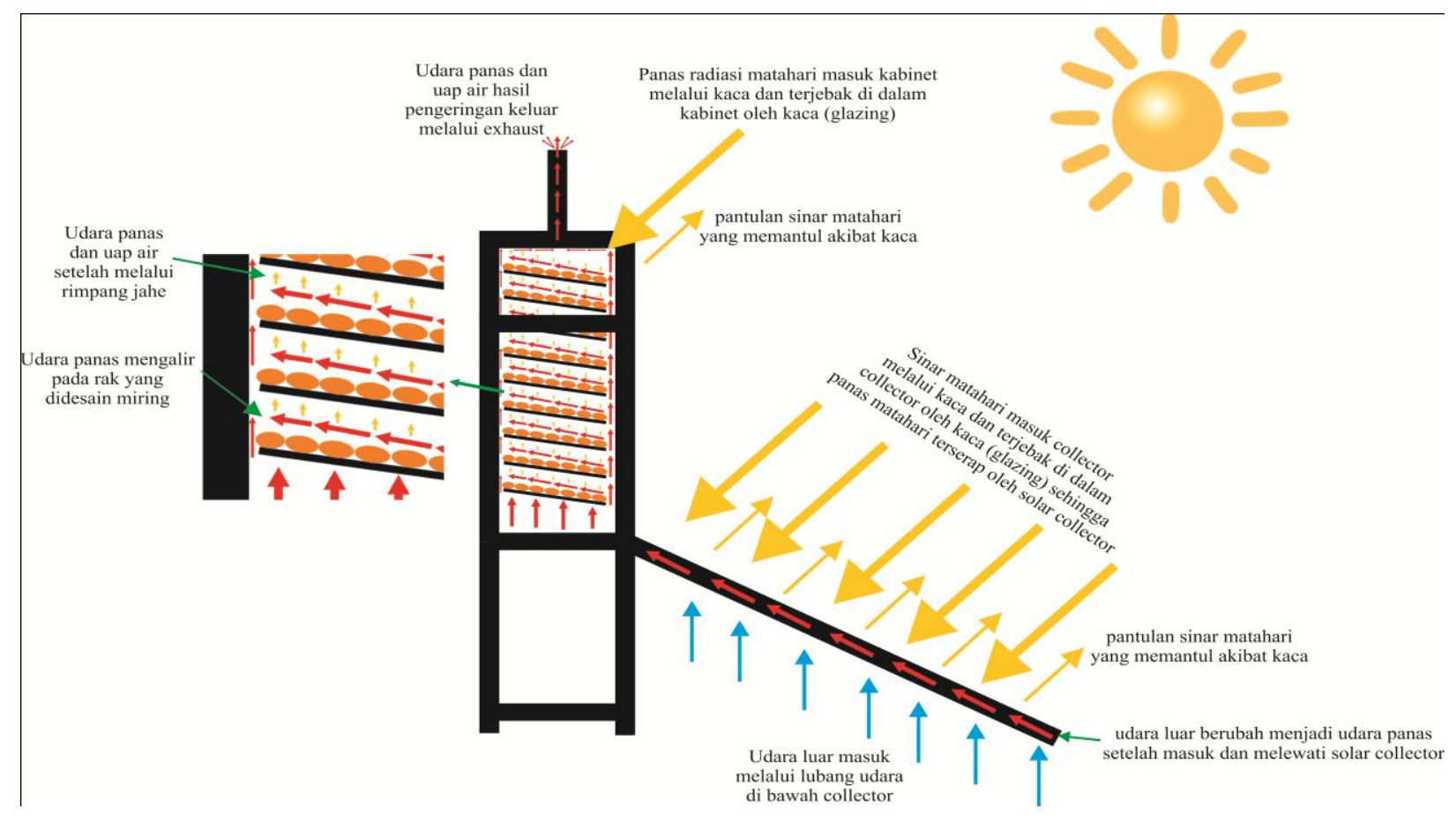

Gambar 1. Kinerja Alat Pengering Bersumber Panas Matahari

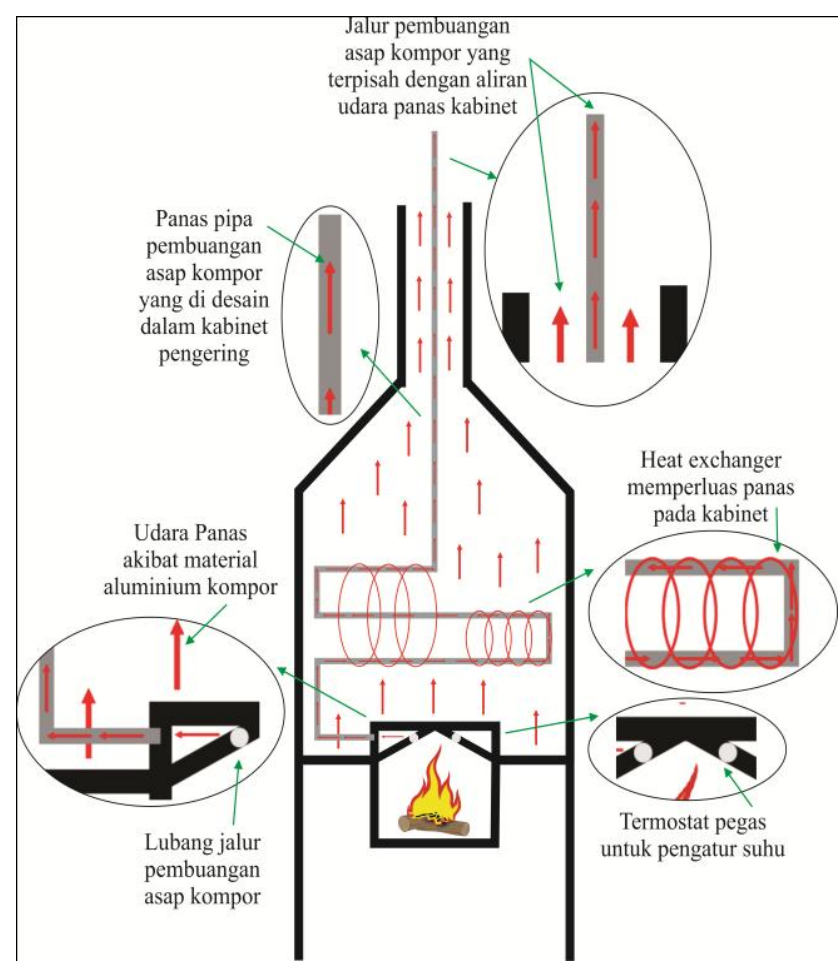

Gambar 2. Kinerja Alat Pengering Bersumber Panas Kompor Biomassa

\section{Kesimpulan}

Konsep alat pengering simplisia untuk para petani Biofarmaka di wilayah Karanganyar yang berhasil dirumuskan berdasarkan kajian ini adalah : alat pengering simplisia dengan sistem pengering matahari tipe kabinet (cabinet solar dryer) dengan kombinasi pemanasan langsung (direct) dan pemanasan tidak langsung (indirect). Mekanisme pemanasan langsung (direct), memanfaatkan kaca tembus cahaya yang dipasang pada atap kabinet pengering. Mekanisme (indirect), memanfaatkan udara yang telah dipanaskan kaca pengumpul panas (solar collector) yang selanjutnya dialirkan alami ke dalam kabinet pengering. Sistem sumber panas cadangan saat tidak ada matahari yaitu dengan menggunakan kompor biomassa, dengan bahan bakar antara lain ranting kayu, arang, atau sekam 
padi. Kompor didesain permanen terpasang pada alat pengering dengan menggunakan material kombinasi kayu dan Aluminium.

Secara rinci dihasilkan 36 konsep produk yang terdiri dari 8 konsep untuk pengeringan bersumber panas matahari, 15 konsep untuk pengeringan bersumber panas kompor biomassa, dan 13 konsep untuk pengeringan sumber panas kombinasi sinar matahari dan kompor biomassa.

\section{Daftar Pustaka}

Badan Standardisasi Nasional, (2005), SNI 01-70872005 : Jahe untuk Bahan Baku Obat, Jakarta: BSN

Fitriani, S., Ali, A., dkk. 2013. Pengaruh suhu dan lama pengeringan terhadap mutu manisan kering jahe (zingiber officinale rosc.) dan kandungan antioksidannya. SAGU : vol 12 no 2 : 1-8.
Herawati, Dian. 2012. Cara Produksi Simplisia yang Baik. Institut Pertanian Bogor (IPB), Seafast Center.

Sembiring, B., Yuliani, S.. 2011. Penanganan dan pengolahan rimpang jahe. Balai Penelitian Tanaman Obat dan Aromatik.

Susilo, Ferry T., Ilham Priyadythama, dan Rahmaniyah D. Astuti. (2014). Perancangan Alat Pengering Simplisia Menggunakan Tenaga Matahari. Prosiding Seminar Nasional IDEC 2014. Surakarta, 20 Mei 2014

Ulrich, Karl T. Eppinger, Steven D. 1995. Product Design and Development. McGraw-Hill, Inc : New York.

Widodo, D., Suryono, dkk. 2009. Pemberdayaan energi matahari sebagai energi listrik lampu pengatur lalu lintas. Universitas Negeri Semarang 